\title{
Effects Of Fish Amino Acid (Faa) Application on Growth and Development of Okra (Abelmoschus Esculentus) at Different Sampling Times
}

\author{
Johari, N. S. ${ }^{*}$, Asilah, A. M. ${ }^{1}$, Zalina, I. ${ }^{*}$, Fazhana, I. ${ }^{1}$, Ab-Latif, Z. ${ }^{2}$, \\ Shaibatul' Islamiah, C. M. ${ }^{1}$, Tang, J. R. ${ }^{1}$ \\ ${ }^{1}$ Agricultural Science Department, Faculty of Technical and Vocational, Universiti Pendidikan \\ Sultan Idris, 35900 Tanjong Malim, Perak, Malaysia \\ ${ }^{2}$ Family and Consumer Science, Faculty of Technical and Vocational, Universiti Pendidikan Sultan \\ Idris, 35900 Tanjong Malim, Perak, Malaysia \\ *Corresponding author, e-mail: zalina.ismail@ftv.upsi.edu.my
}

\begin{abstract}
An experiment was conducted to determine the effects of fish amino acid (FAA) application on growth and development of okra (Abelmoschus esculentus) with different sampling times. It was placed at Soil Science Laboratory, Blok Pakar at the Universiti Pendidikan Sultan Idris (UPSI). The okra plant was treated with a different amount of FAA ( $5 \mathrm{~mL}$ and $10 \mathrm{~mL}$ ). Total of experimental units were 24. The used experimental design was Randomised Complete Block Design (RCBD). The parameters such as root length, shoot length, plant biomass, soil $\mathrm{pH}$ and soil moisture content were analysed after 2 weeks and 4 weeks of transplanting. The data was analysed by using Analysis of Variance (ANOVA), Statistical Package for the Social Sciences (SPSS) and means comparison were using Tukey HSD test with significant level $(\mathrm{P} \leq 0.05)$. Results showed that FAA application and different sampling times were significantly affected the shoot length of okra. Besides, the volume of FAA and the number of weeks were significantly affected the soil $\mathrm{pH}$ and the soil moisture content, respectively. However, the addition of FAA application did not affect the root length and plant biomass of okra.
\end{abstract}

Keywords: Okra; Fish Amino Acid; Sampling Times; Plant growth; Plant Development.

How to Cite: Johari, N.S. et. al. (2020). Effects Of Fish Amino Acid (Faa) Application On Growth And Development of Okra (Abelmoschus Esculentus) at Different Sampling Times. Journal of Vocational Education Studies, 3(2), 35-42. DOI: https://doi.org/10.12928/ joves.v3i2.2932.

\section{INTRODUCTION}

Okra (Abelmoschus esculentus) is an example of fruit vegetable besides tomato, and chili. It plays an important role in human and has beneficial effects on some of the important human diseases (Gemede et al., 2014). Okra known in English as ladies' fingers English and bhindi in Urdu, is a green flowering plant belong to family Malvacae (Khandaker et al., 2017; Ayub et al., 2018). In order to fulfil the demand of okra, there are many ways to increase production. One of the methods is fertilizer application. Fertilizer is a substance that added to the soil to supply nutrients to the plant with the aim of improving yield and quality of the crops. The use of fertilizers is very important for agricultural sustainability. Modern agriculture relies heavily on the use of fertilizers, especially nitrogen-based fertilizers in order to increase crop production. The use of chemical fertilizer can speed up crop yields and is much preferred by farmers in producing quality crops. However, the excessive usage of chemical fertilizer causes air and ground water pollution and causing health problem in human. Therefore, the usage of organic fertilizer is an alternative way to replace the chemical one.

Organic fertilizer is a natural fertilizer produced by the decomposition of animal and plant waste. Moreover, organic fertilizer is environmentally friendly as it is produced 
without the use of chemicals. It is typically found to be an appropriate way of maintaining soil fertility and plant growth (Ji et al., 2017). Fish amino acid (FAA) is one of the organic preparations which is used for improving crop growth development (Priyanka et al., 2019). The FAA is prepared by mixing the fish waste with brown sugar and is left for a fermentation period of at least three months. It is of great importance for the growth of both plants and microorganisms, since it contains different nutrients and amino acid types (Ramesh et al., 2020). During the early or vegetative stage of development, FAA is used as a nitrogen source to improve growth and size (Weinert et al., 2014). Foliar application or soil drenching of fish amino acids may increase uptake and reduce runoff or leaching, providing the plant with enough $\mathrm{N}$ for chlorophyll output to maintain plant health (Priyanka et al., 2019). Commercially available fertilizers are a cost-effective way to supplement soil with nitrogen $(\mathrm{N})$ for plant growth and high crop yields, however, inappropriate or excessive use of $\mathrm{N}$ fertilizers may lead to ground or surface water nitrate contamination. (Foley et al. 2012; Weinert et al., 2014).

Because of this issue, many researchers conducted research to produce an organic fertilizer that can be used by farmers without causing harm to the environment and the ecosystem. Therefore, the aim of the study is to determine the effect of fish amino acid (FAA) on plant growth and development of okra at different sampling times.

\section{RESEARCH METHOD \\ Location of experiment}

This experiment was conducted at the Soil Science Laboratory, Blok Pakar, Sultan Abdul Jalil Shah Campus, Universiti Pendidikan Sultan Idris (UPSI).

\section{Planting Material}

Okra seeds were used as a planting material in this research. The seeds were sown in the seedling tray for about 14 days to germinate. After that, the best seedlings were chosen and transplanted into 24 pots with growth media which were mixed soil-FAA fertilizer according to the treatments at different sampling times.

\section{Preparation of Fish Amino Acid (FAA) Fertilizer}

Fish Amino Acid (FAA) fertilizer was prepared using the waste product from the fish. The fish that used in this experiment was long jawed mackerel. The making process for this liquid organic fertilizer was a waste product from the fish was mixed with the brown sugar with ratio $1: 1$ and the treatment were left for three weeks. After three weeks, the solution was filtered and $1 \mathrm{~mL}$ of the solution was added with $1 \mathrm{~L}$ of distilled water. This solution was used with different volume as the treatments for the study.

\section{Treatment}

The okra was treated with different volume of FAA fertilizer at different sampling times. The volume of FAA fertilizer used for treatments were $0 \mathrm{~mL}, 5 \mathrm{~mL}$ and $10 \mathrm{~mL}$. Four replications were used for each treatment and the total amount of experimental units were 24. Data collection was done after the harvesting process at the Soil Science Laboratory for further analyses.

\section{Agricultural practices}

Normal practices were done to the plants. All okra plants were watered manually twice a day in the morning and evening. The fallen leaves were removed and manual weeding was done in order to prevent the competition of the nutrient and space between the plants and the weeds. 


\section{Harvesting}

There were two different sampling times of harvesting of the okra plants. The first harvesting was done in two weeks after transplanting, while the second harvesting was done after four weeks of transplanting. All the samples were cleaned under the running tap water and the excessive water was drained off using tissue paper and ready for the analyses.

\section{Data collection after harvesting process}

The following parameters such as root and shoot length, plant biomass, soil pH, soil moisture content were measured and analyzed after harvesting.

\section{Root and shoot length}

Root and shoot length from each treatment were measured by using a tape measure. The results of the measurement were recorded.

\section{Plant biomass}

All the plants from each treatment were put in an envelope. All the samples were dried in the oven at $70^{\circ} \mathrm{C}$ for 24 hours. After that, the samples were weighed by using a digital scale.

\section{Soil $\mathrm{pH}$ analysis}

Soil $\mathrm{pH}$ indicates the degree of acidity or alkalinity of the plant. The air-dried soil was weighed using digital scale. The $\mathrm{pH}$ meter was calibrated using the buffer solution, then soil pH (1:25; fresh soil: distilled water) was determined by using a pH meter.

\section{Soil moisture content}

The remaining fresh soil was oven-dried at $105^{\circ} \mathrm{C}$ for 24 hours until constant weight was achieved. Soil fresh weight and dry weight of each treatment were recorded. The soil moisture content was calculated.

\section{Statistical analysis}

An experimental design used was Randomized Complete Block Design (RCBD) with 4 replications. The data was analysed by using Analysis of Variance (ANOVA), SPSS Statistical Analysis and the differences between treatments mean were determined using Tukey HSD test with significant level $(\mathrm{P} \leq 0.05)$. The significant interaction between FAA fertilizer at different sampling times on the root and shoot length, plant biomass, soil $\mathrm{pH}$ and soil moisture content were analysed.

\section{RESULTS AND DISCUSSION \\ Root length}

There were no significant differences of root length among the treatments in Figure 1. However, the volume of $5 \mathrm{~mL}$ of fish amino acid (FAA) application on root length showed the highest root length followed by treatment with $0 \mathrm{~mL}$ of FAA and $10 \mathrm{~mL}$ of FAA ON Week 2. It shows on the Week 2, the addition of FAA affected the root length. Ji et al. (2017) have shown that liquid organic fertilizer (shrimp extract) treatment has produced the significant increase in root dry weight, total length, surface area, volume, tips and thick root length, respectively. Treatment with $0 \mathrm{~mL}$ of FAA showed the highest root length compared to the treatment with $5 \mathrm{~mL}$ of FAA and $10 \mathrm{~mL}$ of FAA on Week 4. Based on the Figure 1, it shows that the root length was decreased from Week 2 until Week 4 at the $5 \mathrm{~mL}$ of FAA application. However, the length of root has increased from Week 2 until Week 4 on $0 \mathrm{~mL}$ and $10 \mathrm{~mL}$. This situation happened might because the factors of the light and water at the location of experiment. 


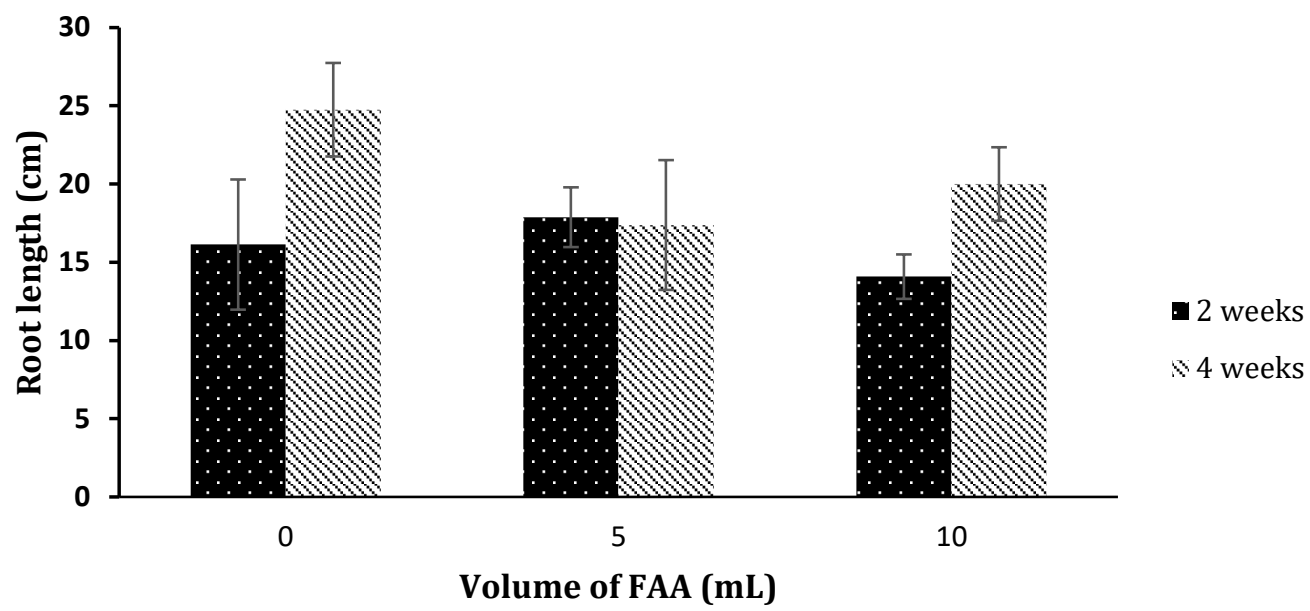

Figure 1. Effect of fish amino acid (FAA) application on root length $(\mathrm{cm})$ of okra with different sampling times

\section{Shoot length}

There were significant differences among the treatments in Figure 2. According to the statistical analysis, the results showed that shoot length was significantly affected by the number of weeks $(\mathrm{P}=0.002)$ and the volume of FAA $(\mathrm{P}=0.049)$ that acted as a single factor. Based on the graph, treatment with $10 \mathrm{~mL}$ of FAA produced the longest shoot length on Week 2 and Week 4. It shows that $10 \mathrm{~mL}$ of FAA applications was affected the shoot length of okra plant. Ji et al. (2017) also showed that, compared to the chemical fertilizer in the short-term pot experiment, the liquid organic fertilizers substantially promoted root and aboveground growth by $10.2-77.8 \%$ and $10.7-33.3 \%$, respectively. Moreover, previous study also reported that foliar application of FAA $1 \%$ increased the plant height, number of leaves per plant and chlorophyll content to the tune of $16.5,12.6$ and $8.1 \%$ respectively over control (Ramesh et al., 2020).

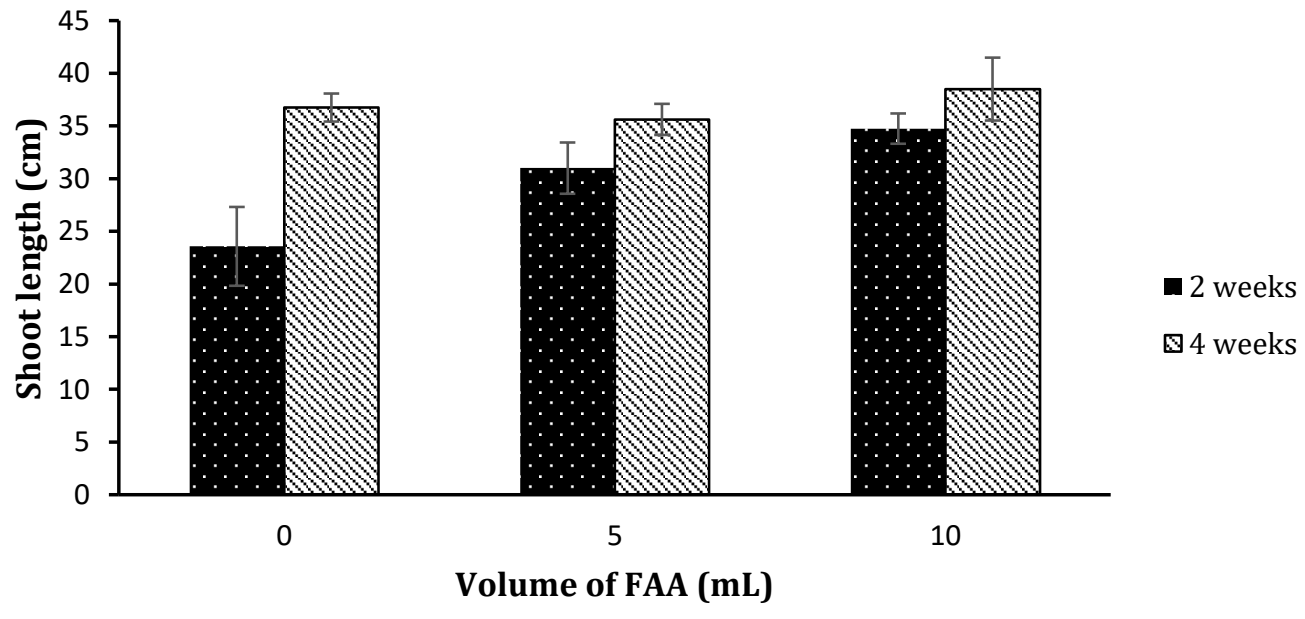

Figure 2. Effect of fish amino acid (FAA) application on shoot length (cm) of okra with different sampling times 


\section{Plant biomass}

For plant biomass, there were no significant differences between the treatments based on Figure 3. However, the treatment with $10 \mathrm{~mL}$ of FAA application to the okra plant showed the highest plant biomass compared to the other volume of FAA which were $0 \mathrm{~mL}$ and $5 \mathrm{~mL}$. It showed that FAA helps to promote the plant biomass of the okra plant. The nutrient in FAA were promoting the plant growth of okra plant. Organic fertilizer application substantially increased the root length of the parent plant, the fresh and dry weight of the root, the fresh weight of the stolon, the fresh and dry weight of the leaves, the fresh and dry weight of the centella biomass. (Trisilawati et al., 2019).

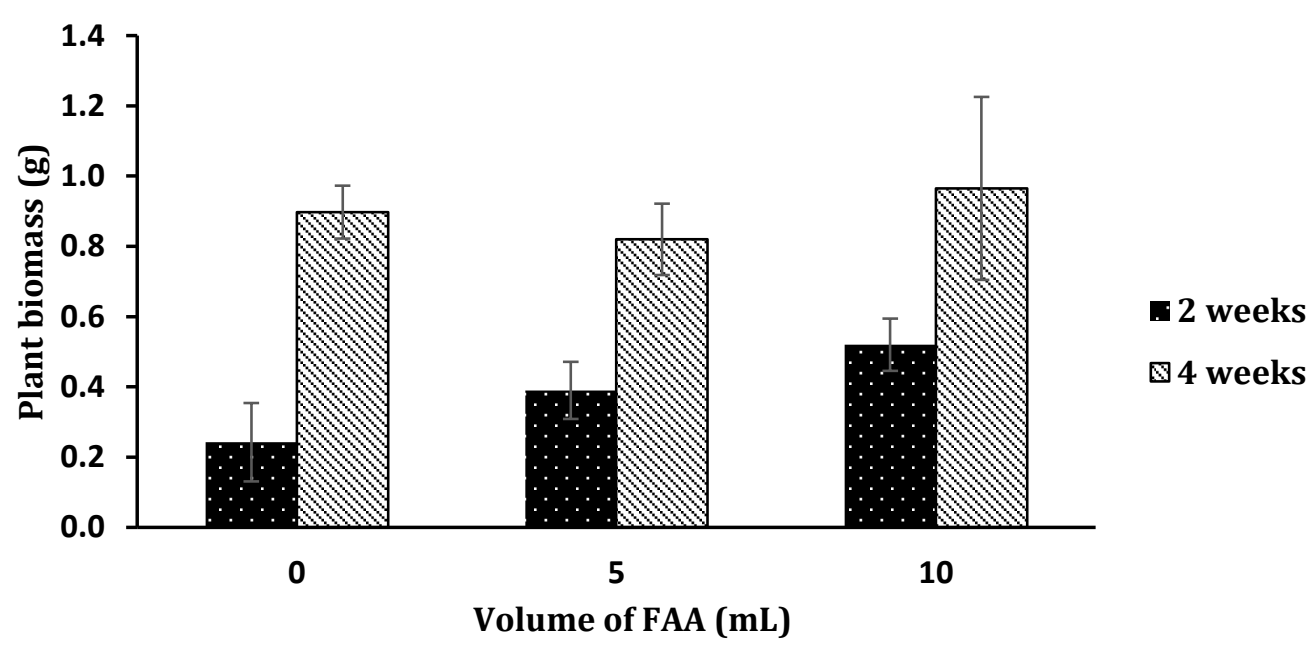

Figure 3. Effect of fish amino acid (FAA) application on plant biomass (g) of okra with different sampling times

\section{Soil pH}

There were significant results among the soil $\mathrm{pH}$ between all the treatments (Figure 4). According to the statistical analysis, the results showed that the soil $\mathrm{pH}$ as a single factor was significantly affected by the volume of FAA $(P=0.019)$. However, the number of weeks and the interaction between the number of weeks with the volume of FAA did not affect the soil pH of okra. Based on the graph below, the treatments that show the better soil pH are the control treatment. It shows that the applied FAA did not improve the soil pH of the okra plants. However, Harishchand et al. (2013) stated in their study that the optimum pH ranges for okra plant is from 6.6 to 8.0 . 


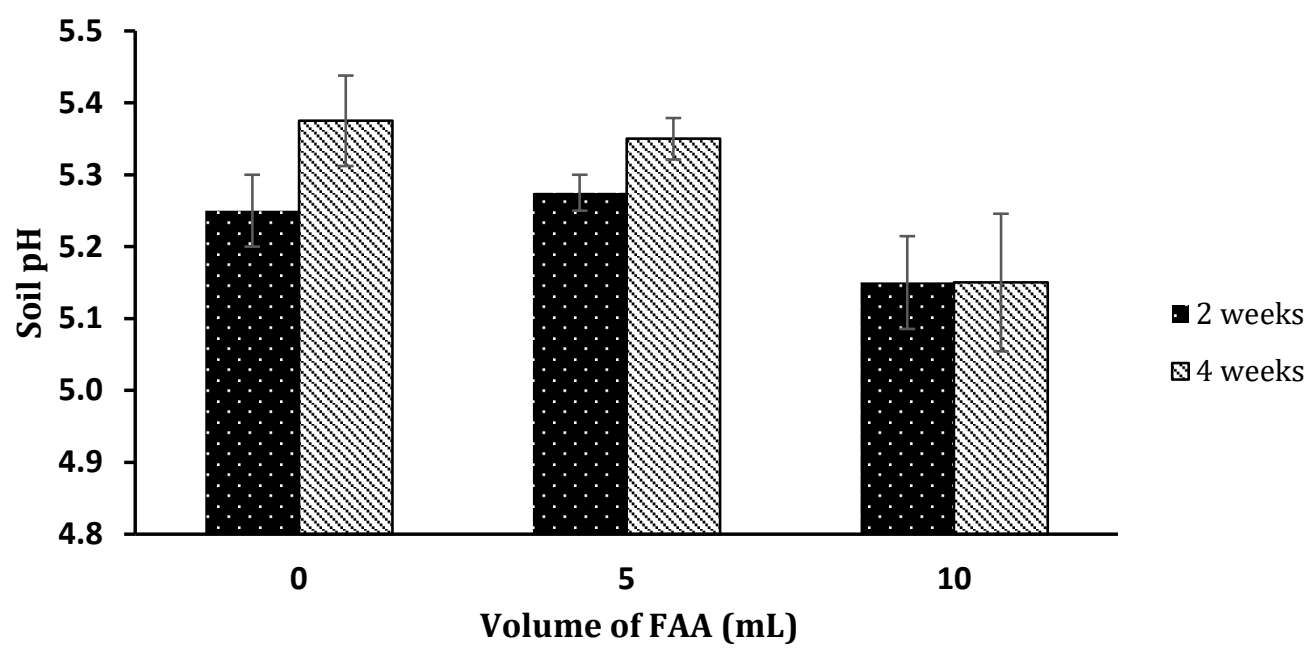

Figure 4. Effect of fish amino acid (FAA) application on soil pH of okra with different sampling times

\section{Soil moisture content}

There were significant differences among the soil moisture content between the treatments (Figure 5). Based on the statistical analysis, the result showed that the soil moisture content as a single factor was significantly affected by the number of weeks $(\mathrm{P}=0.002)$. The graph below shows that the treatment with $0 \mathrm{~mL}$ of FAA (control treatment) showed the highest value of soil moisture content. This shows that the applications of FAA to the okra plant did not affect the value of the soil moisture content. Harishchand et al. (2013) indicated that for okra cultivation, a well-drained fertile soil with a sufficient content of organic matter and reserves of the main elements is generally acceptable. Some varieties are vulnerable to excessive soil moisture. Others are slightly salt-tolerant. However, according to the statistical analysis, the volume of FAA as a single factor did not affect the growth and development of okra plant neither the interaction between the number of weeks and the volume of FAA.

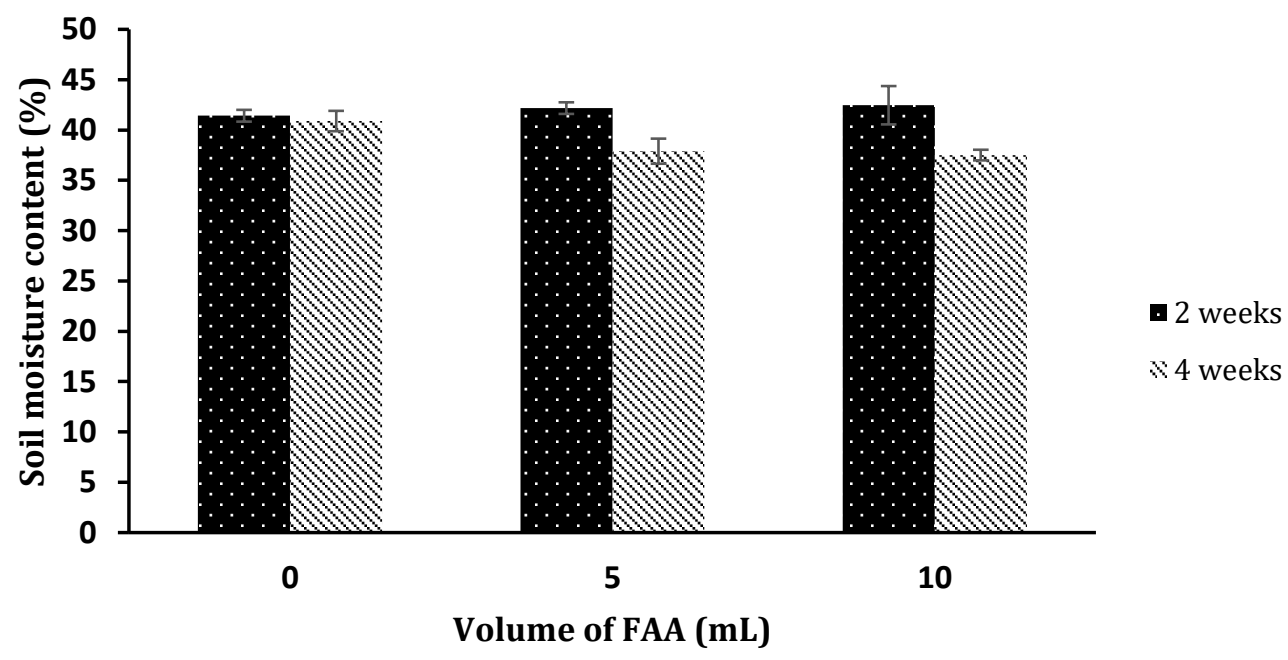

Figure 5. Effect of fish amino acid (FAA) application on soil moisture content (\%) of okra with different sampling times 


\section{CONCLUSION}

The use of liquid organic fertilizer such as FAA appears to be a promising alternative to chemicals. However, there were no significant differences on root length and plant biomass. The addition of FAA fertilizer did not affect the parameter of root length and plant biomass. On the other hand, the results showed that shoot length was significantly affected by the number of weeks and the volume of FAA as a single factor. Moreover, the soil pH as a single factor was significantly affected by the volume of FAA and the soil moisture content as a single factor was significantly affected by the number of weeks.

\section{REFERENCES}

Ayub, Q., Khan, S. M., Hussain, A. K. I., Ahmad, Z. \& Khan, M. A. (2018). Effect of gibberellic acid and potassium silicate on physiological growth of Okra (Abelmoschus esculentus L.) under salinity stress. Pure and Applied Biology, 7, 8-19.

Foley, K. M., Doniger, A. R., Shock, C. C., Horneck, D. A. \& Welch, T. K. (2012). Nitrate pollution in groundwater. Sustainable Agriculture Techniques, Oregon State University, Department of Crop and Soil Science Ext/CrS 137.

Gemede, H. F., Ratta, N., Haki, G. D., Woldegiorgis, A. Z. \& Beyene, F. (2014). Nutritional quality and health benefits of okra (Abelmoschus esculentus): A review. Global Journal of Medical Research.

Harishchand, R., Khan, M. M. \& Singh, P. K. (2013). Effect of spacing and cultivars on growth and yield of okra [Abelmoschus esculentus (L.) Moench]. Asian Journal of Horticulture, 8, 507-511.

Ji, R., Dong, G., Shi, W. \& Min, J. (2017). Effects of liquid organic fertilizers on plant growth and rhizosphere soil characteristics of chrysanthemum. Sustainability, 9, 841.

Khandaker, M. M., Jusoh, N., Hafiza, Ralmi, N. H. A. A. \& Ismail, S. Z. (2017). The effect of different types of organic fertilizers on growth and yield of Abelmoschus esculentus L. Moench (Okra). Bulgarian Journal of Agricultural Sciemce, 23, 119-125.

Priyanka, B., Anoob, D., Gowsika, M., Kavin, A., Sri, S. K., Kumar, R. V. K, Gomathi, R. S., Sivamonica, B., Devi, G. V., \& Theradimani, M. (2019). Effect of fish amino acid and egg amino acid as foliar application to increase the growth and yield of green gram. The Pharma Innovation Journal, 8, 684-686.

Ramesh, T., Rathika, S., Murugan, A., Soniya, R.R., Mohanta, K.K., \& Prabharani, B. (2020). Foliar spray of fish amino acid as liquid organic manure on the growth and yield of Amaranthus. Chemical Science Review and Letters, 9, 511-515.

Trisilawati, O., Hartoyo, B., Bermawie, N., \& Pribadi, E.R. (2019). Application of AMF (Arbuscular Mycorrhizal Fungi) and Organic Fertilizer to Increase the Growth, Biomass and Bioactive Content of Centella. IOP Conference Series: Earth and Environmental Science, 292, 012067.

Weinert, E. J., Miller, S. A., Ikeda, D. M., Chang, K. S., McGinn, J. M., \& DuPonte, M. W. (2014). Natural Farming: Fish Amino Acid. Sustainable Agriculture, SA-12. University of Hawai'i, College of Tropical Agriculture and Human Resources. 
